\title{
The Aboriginal Version ERNA BRODBER'S "ONE BUBBY SUSAN"
}

By Michelene Adams

https://doi.org/10.15362/ijbs.v13i0.62

\section{Abstract}

In the story "One Bubby Susan" (1990), by Jamaican sociologist and author Erna Brodber, the narrator attempts to persuade the listener that a petroglyph in a cave in Jamaica that has been identified in texts as the depiction of an Arawak female is, in fact, not a work of art, but the outline of an actual woman's body. The outline was left in the rock when she was stoned to death by her own people. The contemporary Jamaican narrator recounts the tale which she has been told by the ghost of the Arawak female herself, and, by telling her life across centuries to the narrator, Susan challenges her own marginalization as Aboriginal and as woman.

In the paper I briefly consider how the Aboriginal has remained on the margins in colonial and even in more modern Caribbean discourse. I examine how Brodber recasts the Aboriginal in the central role. First, I consider how she questions the authority of official Histories and scribal culture generally. Then, I explore how the Arawak is re-vivified through the metaphors of the body and the voice. Of course, the issues of history, corporeality and voice are all crucial in feminist discourse, so I also explore what Brodber is suggesting with regard to gender while re-presenting the Aboriginal.

In Erna Brodber's short story "One Bubby Susan" (1989-1990), the contemporary Jamaican narrator, who is apparently black and female, recounts the tale of an Arawak woman called Susan, as told to her by the Aboriginal woman herself. Interestingly, the story begins immediately before Europeans made landfall in Jamaica and includes references to the turmoil that they introduced straight away to Arawak society. The narrator attempts to persuade the reader that a petroglyph in a cave in Jamaica, which has been identified in texts as the depiction of an Arawak woman, is, in fact, not a work of art but the outline of Susan's body. The outline was left in the rock when she was stoned to death by Arawaks like herself. By telling her life across centuries to the narrator, Susan challenges her own marginalisation in history as Aboriginal and female.

The near complete decimation of the Aboriginal has left great interstices in the region's history. Because their fractional record has failed to truly legitimise 
them, the Amerindians of this region remain fixed as the Other in Eurocentric scholarship and linger only vaguely in the Caribbean consciousness. Although the logbooks and journals of explorers and missionaries contain accounts of these peoples, and archaeologists and anthropologists have unearthed fragments of their existence, our conception of them is far from whole or even accurate. In his examination of the encounter between Europeans and Aboriginals of the Caribbean, Peter Hulme (1986) contends that colonial discourse created a binary impression of Amerindians - "fierce cannibal and noble savage" - that has been corroborated even by modern history texts, and he argues further that anthropological studies have tended to extend the ethnic stereotyping (47). Our conception of the Aboriginal grows out of a Eurocentric vision combined with myth. As well, because they had all but disappeared within one century, they are associated with the sense of victimisation that once preoccupied the region's intellectuals. In fact, unlike the slave, the other principal victim in Caribbean history, the Amerindian is not merely abused but silenced and virtually erased.

Modern Caribbean narrative has dealt only infrequently with Amerindians. Wilson Harris has always insisted that they have played a crucial role in the formation of the Caribbean psyche and that their culture should be tapped as a wellspring of creativity by the people of the region, and lately Jamaica Kincaid has allegorised the experience of the region's Aboriginals in the short story "Ovando" and in the illustrated children's book Annie, Gwen, Lily, Pam and Tulip (1989). What Brodber does here, however, is humanise the Amerindian. Her Susan is a real character in the narrative, a female character whose actions and the motivation behind them are revealed to the reader and are comprehensible. Brodber draws the region's first peoples into Caribbean discourse, giving them a voice on fundamental post-colonial issues such as the precedence of scribal over oral narratives; the validity of History; the de-subjectification of the Other; and the targeting of gender as a basis for oppression.

Erna Brodber (1983) takes issue with the assumption that oral narratives are less true than written ones in "Oral Sources and the Creation of a Social History of the Caribbean." She lays the blame for the region's invalidation of the oral on colonialist and neo-colonialist theory and practices. She believes that with the influence of European culture, "the printed word assumes high value in all sectors of Caribbean societies and knowledge consequently becomes defined as 'that which is found in books'” (2). The first sentence of "One Bubby Susan" mentions Frank Cundall, the librarian and author who was Secretary of the Institute of Jamaica from 1891-1937 (52). The narrator names the Englishman as the source of what is recorded about the pre-Columbian petroglyph. However, although " $[\mathrm{w}]$ hat in book is gospel so everybody go believe" (52), she does not allow the reader to view the text as unassailable. With regard to Cundall's scholarship on the carving, she declares, "I am here to tell you that nothing don't go so" (52). She connects Europeans to the cult of academics, remarking, "Just them white people and them scribes again” (52). Brodber links Europe with linearity and logic, then suggests they are not failsafe means of arriving at the truth.

Peter Hulme (1986) argues that

Writing is kept as much as possible as the defining characteristic of western culture... Anthropology has consistently operated this dichotomization: primitive and civilized, non-literate and literate. It has functioned to divide the world into two, one part (ours) that can be taken at its word, the 
other (not ours) that needs the interpreting voice of the anthropologist to make it comprehensible (to us).

The ways of seeing and the modes of scholarship of the West ensure that oral cultures are cut off from history, and it is assumed that their "mute remains" are unequal to the "incontrovertible evidence" that written records provide (56). Hulme insists, however, that despite the importance of written evidence, other items that reflect a culture - even items as distinct from the word as stone artefacts, for example - are types of texts, and "both must be read" because "history is indivisible" (56).

Brodber addresses this issue in "One Bubby Susan”, firstly by creating a very oral narrative in the Nation Language of Jamaica. As Helen Tiffin (1993) acknowledges, "the body of Arawak Susan is reanimated in Creole instead of in 'authoritative' Euro-historical discourse, and the tone is gossipy, not scholarly" (910). The narrator is suspicious of Cundall's scholarship and she asks boldly, "Them long long time when Cundall writing, where them get camera to go take picture of Miss Susan? You no see something not too quite right?" (52) The distinctly Jamaican voice of her narrator interrogates both the hegemony of the language of the empire and that of the written word.

As Ashcroft, Griffiths and Tiffin (1995) state, "Clearly, what it means to have a history is the same as what it means to have a legitimate existence" (355). However, the Western emphasis on applying formal scholarship in the process of learning has reduced history to its function as a discipline, and, as a result, European scholars have been allowed to define the Other according to their limited academic vision. As Robert Young (1990) puts it,

"History, with a capital $\mathrm{H}$, ... cannot tolerate otherness or leave it outside its economy of inclusion. The appropriation of the other as a form of knowledge within a totalizing system can thus be set alongside the history (if not the project) of European imperialism, and the constitution of the other as 'other' alongside racism and sexism."

When Cundall records that the carving is a work of art, Susan's life passes unobserved. There is room in the text for an academic discussion of what this archaeological find has contributed to the records on the Aboriginal but none for the kind of history that Brodber writes.

Nevertheless, the narrator of "One Bubby Susan" casts doubt upon the empirical research methods that have defined Jamaica when she states, "Is just these white people like come to people country, look roun two time, take photo, measure this and measure that" (52). She scorns their unwillingness to regard their discoveries in an introspective manner, and she is insulted too by their refusal to consult the people themselves, complaining that the researchers "no ask nobody no question, no sit down and meditate, and baps - them have answer" (52). She has learned the true story behind the outline of the body from the ghost of the Arawak woman herself: "I am sitting down quiet to myself when my ears start to tingle and I get a strong smell of that flowers that we used to string as bead. The smell so strong, I nearly faint and then the lady start to talk and she tell me" (52). In contemplation, the narrator is receptive to enlightenment. This is an utterly different approach to learning - an old world approach that has little credence in the West. It recalls the ways of Aboriginal shamans who communicate with spirits to bring understanding to their people. The narrator adopts the worldview of the original people of 
A society's concept of time shapes the way in which it apprehends history. The Western notion of diachronism restricts history to points on a timeline. By insisting on formally documenting the past, people who privilege scribal communication are able to easily perceive history as a closed chapter. However, the Old World vision of temporal cycles as opposed to lines, allows for the unimpeded flow of time. Thus, the narrator does not need to read history. It courses to her across five hundred years in the voice of the dead, and her nonEuropean sensibility allows her to accept this ghost's account of the past as truth: "I don't know why Miss Sue want me to tell this story but I tell it," the narrator states plainly, adding, "Perhaps want to set the record straight" (53). Although Aboriginals rarely appear in West Indian fiction, there are various connections between them and the largest ethnic group in the region. Walker (1992) believes that "Caribbean history is a long recitation of human suffering because the prolonged crime of African slavery that marred that history for centuries had been preceded by the genocide of the Island Arawaks" (34), but in this narrative more than their common suffering is highlighted. Their shared vision of synchronic time allows the Aboriginal to speak to the African across centuries and the African to hear her, and through this communication they resist colonisation of the mind and the spirit.

In the image of the erasure of the body is figured the ultimate de-subjectification, According to Tiffin (1993), "Susan's history offers an allegory of the extirpation of the female fleshly body under colonialism - both in terms of military invasion and textual capture - leaving only a vague outline in rock" (910). The historical records have reduced the Aboriginal to a petroglyph, a work of art through which a male sculptor, another version of the male author, is able to de-actualise her. But the narrator objects to History's misinterpretation of Susan: "I know this man Cundall shoulda-eh study him head well before him go call Miss Sue this flesh-and-blood woman a carving," she states dryly (53). Here Brodber creates a complex trope in which feminist and postcolonial codes are intertwined, as both schools conceive of the body as a figure for substantiality.

Postcolonial writers use the emblem of corporeality to affirm their subjectivity because " $[t]$ he body is an endlessly suggestive sign through which the process of 'subjectification' is mediated and expressed" (Dash, 1989: 20). It is the region's history that originally caused the emblem of the body to be lodged in the Caribbean psyche: the Amerindians, whose bodies were not equal to the tasks set by Europeans, were eradicated by the coloniser and replaced by Africans who were valued only for what their bodies could achieve through their labour. In Caribbean narrative, "[t]he ever-shifting unstable relationship between body and non-body, between dis-membering and re-membering, is a continuous aesthetic and thematic concern" (Dash, 1989: 20). As a result, the question of Susan's existence - is she merely a carved representation of a woman or was she an actual being? — is a fundamental one.

The figure is also key in feminist studies since the body — "particularly the female body - has been constructed [and deconstructed] through ideologies, discourses and practices" (Conboy, 1997: 53). The tribeswoman leaves her community and tries to live as a hermit in a cave some distance from her people's villages because she is unwilling to accept a typical Arawak woman's fate: marriage, motherhood and domesticity. When she is discovered living 
alone in the wilderness, the members of a related Arawak group are sufficiently unsettled to assume that she is a goddess. The implication is that she is so far removed from the circumscribed space of human females that she must be a supernatural creature. Thus, they proceed to objectify her: she is garlanded, animal sacrifices are made to her and her excrement is prized as "gold from the gods" (54). This treatment satirises the objectification of women in general, and, significantly, the tribespeople move from worshipping her to abusing her when she refuses to conform to the role of goddess. In a malecentred culture, women who will not play the designated female roles have no place in society; thus, they often must live on the margins of society, and sometimes they are obliterated, as Brodber's Arawak is.

Of course, feminists also connect the concept of corporeality to that of language. Hélène Cixous (1980) declares,

"Nearly the entire history of writing is confounded with the history of reason, of which it is at once the effect, the support, and one of the privileged alibis. It has been one with the phallocentric tradition. It is indeed that same self-admiring, self-stimulating, self-congratulatory phallocentrism."

In drawing an analogy between scribal culture, the masculine principle, and the notion of power, Gilbert and Gubar (1970), in their seminal feminist study, suggest how the male with his phallic pen contributes to the objectification of the female. In writing, the author identifies with god the father, the author of humankind. Thus, the lives of those who do not control the means of scribal communication are written by the scribes. The history of Jamaica has been recorded for hundreds of years by white, male writers. The logbooks of the conquistadors and the other original settlers, the journals of Creoles, and even the modern History texts of the first sixty years of the 20th century have almost invariably been written by men. The female voice has been silent, and when women are represented in these texts, it is as the male author perceives them - generally passive and limited to their circumscribed spaces. The Aboriginal woman's body is absent from history; in the text she is not subject but object. However, because the body and the voice are tied through "the inextricable relationship between verbal and physical self-assertion" (Dash, 1989: 21), readers may conclude that Susan re-vivifies herself through speech.

We need to recall, though, that women of colour take issue with the totalisation of feminism by European theorists. For those who during their violent histories have endured rape, torture, scarring, mutilation, etc., "“writing the body" is much more problematic than it is for the European females to whom Cixous' exhortation was addressed (Easton, 1994: 1). However, as Easton argues, black women writers have discovered that, for them, the key to "writing the body" is to forge a passage through history, for "body and history are bound together: the route into a new space must be through both that body and that history, because one cannot write one without the other" (3). Brodber uses corporeal images positively to suggest how Caribbean women have challenged History. She breaks the silence that surrounds the Arawak in History by giving Susan a voice.

Further, the narrator of "One Bubby Susan" emphasises that she has not dreamt the tribeswoman's life in visual images: "the lady start to talk and she tell me," and through her account Susan is re-embodied. The emphasis on voice as the instrument and on Nation Language as the optimum medium for 
asserting the suppressed self is common in black women's narrative. In writing by women of Africa and of the diaspora, females regularly empower themselves through the medium of their own distinctive voices. Western feminists contend that because of the hegemony of the male in Western discourse, women need to speak "through semiotic gaps, silences, contradictions and disruptions within the symbolic order" (Easton, 1994: 4). However, as highly flexible languages that have been devised by the people of the Caribbean themselves, Nation Languages provide a channel through which Caribbean women may articulate themselves (Easton, 1994: 4).

Obviously Brodber has a deep awareness of how the treatment of the body in narrative might contribute to the healing of the Caribbean and female psyches. In order to dispute the written word, she invokes the region's original people. Susan does not return in the flesh; nevertheless, her voice functions to challenge History and to place her as the subject at the centre of the new text. Brodber's handling of these crucial Caribbean and post-colonial concerns is especially consequential because she sets the narrative at the source of Antillean history - when Europeans made landfall and created the notion of a discrete pre-Columbian time by annihilating an entire culture. In re-animating the Aboriginal, she begins to bridge those sundered worlds.

\section{References}

Ashcroft, B., Griffiths, G., \& Tiffin, H. (Eds.) (1995). The post-colonial studies reader. New York: Routledge.

Brodber, E. (1989-90). One bubby Susan. Jamaica Journal, 224, 52-53.

Brodber, E. (1983). Oral sources and the creation of a social history in the Caribbean. Jamaica Journal, 16 (4), 2-11.

Cixous, H. (1980). The laugh of the Medusa. In Elaine Marks and Isabelle de Courtivron (Eds.) New French feminisms: An anthology. (pp 245- 264). Amherst: U of Massachussets Press.

Conboy, S. (1997). Body. In Elizabeth Kowaleski-Wallace (Ed.), Encyclopedia of feminist literary theory. (pp. 53-55). New York: Garland.

Dash, J. M. (1989). In search of the lost body: Redefining the subject in Caribbean literature. Kunapipi. 11(1), 17-26.

Easton, A. (1994). The body as history and "writing the body": The example of Grace Nichols. Journal of Gender Studies. 3 (1), 55-67.

Gilbert, S., \& Gubar, S. (1970). The madwoman in the attic: The woman writer and the nineteenth century literary imagination. New Haven: Yale UP.

Hulme, P. (1986). Colonial encounters: Europe and the native Caribbean, 14921797. London: Methuen.

Newson, L. A. (1976). Aboriginal and Spanish colonial Trinidad: A study in culture contact. London: Academic.

Tiffin, H. (1993). Cold hearts and foreign tongues: Recitation and the reclamation of the female body in the works of Erna Brodber and Jamaica Kincaid. Callaloo. 16 (3), 909-921.

Young, R. (1990). White mythologies: Writing history and the West. London: Routledge.

Michelene Adams is a Trinidadian who spent eighteen years in Canada before traveling to New Providence to teach at the College of The Bahamas. Her area of scholarly interest is Caribbean women's narrative, and she teaches courses in composition and literature in the School of English Studies. She is currently working on her doctoral dissertation at the University of New Brunswick, Canada. 